\title{
THE LEVEL OF NICOTINE DEPENDENCE IS AN INDEPENDENT RISK FACTOR FOR CANCER. A CASE CONTROL STUDY
}

\author{
Daniel Deheinzelin, Maria Teresa Cruz Lourenço, Célia Lidia da Costa, and Riad \\ Naim Younes
}

\begin{abstract}
Deheinzelin D, Lourenço MTC, Costa CL da, Younes RN. The level of nicotine dependence is an independent risk factor for cancer. A case control study. Clinics. 2005;60(3):221-26.
\end{abstract}

BACKGROUND: Less than $20 \%$ of lifetime smokers will ever develop cancer. Smoking habits characteristics, particularly the level of nicotine dependence level, were not fully evaluated as a marker of risk.

METHODS: Case-control study of voluntary patients prospectively enrolled in a smoking cessation program in a cancer hospital. For each cancer case, patients of the same age and sex were selected. The Beck Depression Inventory, an instrument for the diagnosis of depressive mood and clinical depression, and the Fagerström Test Questionnaire, a questionnaire that has a good correlation with nicotine levels, used to determine the degree of dependence on nicotine, were applied. Age on admission to the study, sex, and number of pack-years were also evaluated.

RESULTS: From May 1999 to May 2002, 56 cancer patients (case) and 85 matching controls (control) were identified in the population studied. There was no difference regarding pack-years. Fagerström Test Questionnaire was significantly higher in patients with cancer $(7.5 \pm 1.9)$ compared to controls $(6.3 \pm 2.0)$. We found a Fagerström Test Questionnaire $\geq 7$ in $73.2 \%$ of the cancer cases versus $43.5 \%$ of the controls $(\mathrm{p}=0.001)$. The proportion of depressed patients was higher in the cancer group $(37.5 \% \times 17.6 \%)$. Logistic regression adjusted for age and tobacco consumption disclosed that Fagerström Test Questionnaire score $\geq 7$ has an odds ratio for cancer of 3.45 (95\% CI $1.52-7.83, \mathrm{p}=0.003)$.

CONCLUSION: Fagerström Test Questionnaire higher than 7 was identified as a risk factor for cancer in smokers with similar tobacco consumption.

KEYWORDS: Smoking cessation. Fagerström Test. Cancer. Tobacco.

Although the role of tobacco smoking as a causative agent for a great number of cancer types is established ${ }^{1-5}$, less than $20 \%$ of lifetime smokers will ever develop cancer $^{6}$. Genetic polymorphism may explain cancer risk through the effects on carcinogen metabolism and detoxification on steps of cellular metabolism, on smoking behavior and nicotine addiction ${ }^{7}$. A possible marker of risk,

Departments of Psychiatry and Thoracic Surgery, Treatment and Research Center, Hospital do Cancer - São Paulo/SP, Brazil.

Laboratory of Medical Investigation of Surgical Physiopathology (LIM62), Hospital das Clínicas, Faculty of Medicine, University of São Paulo São Paulo/SP, Brazil.

Universidade Paulista (UNIP) - São Paulo/SP, Brazil.

E-mail: daniel@hcancer.org.br

Received for publication on October 25, 2004.

Accepted for publication on March 07, 2005. the nicotine dependence level, has not been fully evaluated in cancer patients before.

Higher nicotine dependence, pointed out by a Fagerströn Tolerance Questionnaire (FTQ) $\geq 7$, was recently described as a prognosticator of failure in tobacco cessation programs ${ }^{8}$. Regarding the incidence of chronic obstructive pulmonary disease (COPD), a clear difference in the level of nicotine dependence and presence of disease in smokers was recently described ${ }^{9}$. Moreover $30 \%$ of smokers with COPD, presented a FTQ greater than seven points, a proportion significantly higher that the found in healthier smokers 9 .

The Fagerstrom Tolerance Questionnaire has been shown to correlate well with tobacco consumption in cancer patients ${ }^{10}$, as well as in non-cancer patients ${ }^{11}$. As such, 
the aim of the present study was to assess whether there is a difference in smoking habits, particularly the levels of dependence between smokers with cancer and those without.

\section{METHODS}

Patients were retrospectively identified from those prospectively enrolled in the Smokers' Support Group at the Hospital do Cancer A.C. Camargo in São Paulo, Brazil. Outpatient smokers enrolled in the group spontaneously.

At the initial interview with a psychiatrist, the Beck Depression Inventory (BDI), an instrument validated for the diagnosis of depressive mood and clinical depression, and the Fagerström Test Questionnaire (FTQ), a questionnaire that has a good correlation with nicotine levels, were applied. The BDI includes 21 questions that screen for depression symptoms. The FTQ comprises smoking habit related questions such as "how long do you take before smoking the first cigarette after awakening?", "which is the worst cigarette to quit?", or "do you smoke when sick?". The questionnaire was used to determine the degree of dependence on nicotine. Following the first visit, subgroups of 15 patients were formed and these subgroups returned weekly for behavioral orientation related to smoking cessation ${ }^{8}$.

Inclusion criteria were age, ranging from 18 to 65 years, and a minimum smoking habit of 15 cigarettes/day in the last year. Cancer patients were identified in the first clinical visit based on their history. Confirmation of the diagnosis of malignancy was obtained from the medical records. A control group was matched by sex and age, tolerating an up to two year age difference for each case. Cancer was excluded in the subjects of this group based on a thorough medical history, a complete physical examination and a chest x-ray. As the clinical status was obtained based on the interview, the only exclusion criterion was patients having any signs of mental impairment or demential syndromes.

\section{Statistical analysis}

Variables determined at the first interview (Beck score, Fagerström test score, age on admission to the study, sex, number of years smoked and cigarettes per day smoked in the last year and finally the number of pack-years someked obtained by the product of the last two variables) were evaluated. Student-T test was used for normal continuous variables, Mann - Whitney test for non normally distributed variables and the Chi-square test for categorical variables. To determine the odds ratio of each variable in relation to cancer, logistic regression was utilized using the enter procedure. For that analysis, depression was established as a Beck score equal to 20 or greater. Fagerstrom was divided into two categories; lower or equal and greater than 7 , as we have recently shown that such categories are directly related to difficulties to quit ${ }^{8}$. The level of significance was established at $5 \%$. Statistical analyses were performed using the SPSS for Windows (8.0).

\section{RESULTS}

From May 1999 to May 2002, 56 cancer patients were identified at the Smokers' Support Group (CASE). Final diagnosis of these cases are described in table1. Eighty-five matching controls were identified in the population studied (CONTROL). The total group completing the study was predominantly female, $64.5 \%$. The age varied between 35 and 70 years with a mean of $51.9 \pm 8.7$ years $($ mean \pm SD) . The Fagerström Test Questionnaire mean was $6.8 \pm 2.0$, with $55.3 \%$ of the entire population presenting a score $\geq 7$. Mean Beck Depression Inventory score was $15.6 \pm 8.6$ with $25.5 \%$ of the study group scoring as depressed. The whole group smoked $23.8 \pm 11.1$ cigarettes per day with a smoking history of $34.6 \pm 9.5$ years.

Table 1 - Histology and primary organ affected in the cancer patients.

\begin{tabular}{llrr}
\hline Histology & Primary Organ & $\mathrm{n}$ & \% of total \\
\hline Epidermoid Carcinoma & Tonsil & 4 & 7.0 \\
& Larynx & 7 & 12.5 \\
& Mouth & 5 & 9.0 \\
& Lung & 5 & 9.0 \\
& Ocular & 1 & 1.8 \\
& Supra Glotis & 1 & 1.8 \\
Adenocarcinoma & Unknown & 1 & 1.8 \\
& Lung & 3 & 5.2 \\
Oat Cell Carcinoma & Ovary & 4 & 7.0 \\
Carcinoma & Thyroid & 2 & 3.6 \\
& Lung & 4 & 7.0 \\
Multiple Melanoma & Cervix Uteri & 1 & 9.0 \\
Sarcoma & Breast & 13 & 1.8 \\
\hline Total & Lung & 2 & 23.0 \\
\hline
\end{tabular}

As expected, we found no significant differences between the two populations regarding sex and age. Neither was there any difference regarding the number of pack-years smoked.

FTQ was significantly higher in patients with cancer compared to controls. We found a FTQ $\geq 7$ in $73.2 \%$ of the cancer cases versus $43.5 \%$ of the controls $(\mathrm{p}=0.001)$. BDI was also significantly higher in the cancer group, as compared to the controls. The proportion of depressed patients was higher in the cancer group (37.5\% x 17.6\%). Univariate analyses for each variable is described in table 2 . 
Table 2 - Univariate analysis of demographics, tobacco consumption, Fagerströn Tolerance Questionnaire and Beck Depression Inventory between cancer patients and matched controls.

\begin{tabular}{lccc}
\hline & Cancer Patients & Controls & P \\
& $\mathrm{N}=54$ & $\mathrm{~N}=85$ & $0.14^{*}$ \\
Sex & $32 \mathrm{~F}: 24 \mathrm{M}$ & $59 \mathrm{~F}: 26 \mathrm{M}$ & $0.31^{\#}$ \\
Age (y) & $52.9 \pm 8.7$ & $51.3 \pm 8.7$ & $0.133^{\#}$ \\
Cigarettes per day & $25.5 \pm 13.2$ & $22.6 \pm 9.4$ & $0.71^{\#}$ \\
Smoking Years & $34.9 \pm 10.6$ & $34.4 \pm 8.7$ & $\mathrm{p}=0.17$ \\
Pack -Years & $43.8 \pm 24.2$ & $38.7 \pm 17.2$. & $<0.001^{\#}$ \\
Fagerström Test & $7.5 \pm 1.9$ & $6.3 \pm 2.0$ & $0.001^{*}$ \\
Fagerström & 3 $7 \%)$ & $43.5 \%$ & $0.022^{\#}$ \\
Beck Depression & $73.2 \%$ & $14.3 \pm 8.2$ & $0.01^{*}$ \\
Inventory & $17.7 \pm 8.9$ & $17.6 \%$ & \\
BDI $>$ 20 & $37.5 \%$ & & \\
\hline
\end{tabular}

* Chisquare, ${ }^{*}$ Students t Test

Logistic regression adjusted for age and tobacco consumption disclosed that FTQ score $\geq 7$ has an odds ratio for cancer of $3.45(95 \%$ CI $1.52-7.83, \mathrm{p}=0.003)$ and depression has an odds ratio of 2,95 (95\% CI 1.27-6.85, $\mathrm{p}=$ $0.012)$. There was no significant association between both variables ( $\mathrm{p}=0.444$, Chi-square).

\section{DISCUSSION}

Comparing cancer patients enrolled spontaneously in a smoking cessation group with those without cancer, only the level of nicotine dependence, assessed by the FTQ, and depression, as assessed by the BDI score, were significantly different. An FTQ higher than 7 was clearly identified as a risk factor for cancer in smokers with similar tobacco consumption.

The increased number of depressed patients in the cancer population was not unexpected. Patients dealing with cancer present a higher Beck Depression Inventory score than patients with other diseases ${ }^{12}$. The prevalence of depression in patients with cancer ranges from $1 \%$ to $53 \%$, depending mostly on the methodology and diagnostic criteria utilized ${ }^{13}$. As such, our finding of $37.5 \%$ of depressed patients depicted by the Beck Depression Inventory, is in accordance with previous data. Interestingly, we found no correlation between depression and nicotine dependence in our study population. Association between the two traits has been described, either with depression increasing the likelihood of nicotine dependence over time as well as high nicotine dependence being associated with a higher rate of first incidence major depression ${ }^{14}$. Since our study did not address temporal effects, this may explain the lack of association we found.

In our view, the most significant finding of our study was a higher level of nicotine dependence in patients with cancer. One possible explanation is that patients who con- tinue to smoke after a cancer diagnosis are highly dependent. However, considering the first cigarette after awakening, more than $75 \%$ of newly diagnosed cancer patients enrolled in a cessation trial can be classified as highly dependent ${ }^{15}$. It is known that, even considering lifetime burning up, only some $20 \%$ of smokers will ever develop cancer $^{6}$. Therefore, the finding of specific risk factors would permit a more focused intervention toward smoking cessation. The clearly established association of cancer and quantities of smoked tobacco ${ }^{1-5}$, involves an a posteriori risk factor. In other words, a person would be at risk after having smoked a certain amount of tobacco. The finding that patients with cancer scored higher nicotine dependence indicates a risk factor that can be established $a$ priori. The reliability of FTQ has been already acknowledged ${ }^{16}$, however its variation over time for the same subject to our knowledge has not been studied so far.

A good correlation between FTQ scores and serum levels of tobacco products is well established ${ }^{17-18}$. As such, the FTQ may be more related to tobacco exposure than the recalled amount of smoked cigarettes, which is subject to a recall bias ${ }^{19}$ and therefore, be a more reliable indicator of risk exposure.

Interestingly, lower nicotine dependence (Fagerstrom score $<6$ ) is associated with a 4 fold odds of long term abstinence in smoking cessation with nicotine patch ${ }^{20}$ and a lower FTQ also predicts higher abstinence from smoking while using Bupropion ${ }^{21}$. Moreover, it was recently reported that nicotine dependence defined by the Fagerstrom test for nicotine dependence (FTQ) predicted one year abstinence better than the Diagnostic and Statistic Manual of Mental Disorders (DSM) definition, suggesting that different aspects of nicotine dependence are captured by the different approaches ${ }^{22}$. The above comments are particularly important since a clear demonstration of decreased risk of lung cancer with smoking cessation even at middle age was re- 
cently described ${ }^{3}$. Although a 3.5 odds ratio for cancer in smokers with a Fagerstrom Score ${ }^{3} 7$ was found in the present study, it is noteworthy that in a population of 157 lung and head neck cancer patients, hence strongly related to tobacco consumption, a group with low Fargestrom score was found, suggesting that nicotine dependence is not the only risk factor ${ }^{10}$.

In summary, nicotine dependence, as measured by the FTQ, seems to be a risk factor for cancer in smokers. Such results need to be confirmed in prospective studies that include not only other risk factors, but also address populations with a single type of cancer.

\section{RESUMO}

Deheinzelin D, Lourenço MTC, Costa CL da, Younes RN. O nível de dependência da nicotina é um fator de risco independente para o câncer. Um estudo caso-controle. Clinics. 2005;60(3):221-26.

OBJETIVO: Menos de 20\% dos fumantes crônicos desenvolverá cancer. As características do hábito de fumar, particularmente o nível de dependência à nicotina, não foram avaliadas inteiramente como um marcador do risco.

MÉTODOS: Estudo caso-controle de pacientes voluntários, registrados prospectivamente em um programa de cessação de tabagismo em um hospital de cancer. Para cada caso de cancer, pacientes da mesma idade e sexo foram selecionados. O inventário de depressão de Beck, um instrumento validado para diagnóstico de estado depressivo e depressão clínica e o questionário de tolerância de Fagerstron, que é usado para determinar o grau de dependência e tem boa correlação com níveis de nicotina, foram aplicados. Idade na admissão ao estudo, sexo, número de maços-anos fumados foram avaliados também.

RESULTADOS: De maio de 1999 a maio de 2002, 56 pacientes de câncer (caso) e 85 controles pareados (controle) foram identificados na população estudada . Não houve diferença quanto ao número de maços-ano. O questionário de tolerância de Fagerstron foi significativamente mais elevado nos pacientes com câncer $(7.5 \pm 1.9)$ comparado aos controles $(6.3 \pm 2.0)$. Encontramos um questionário de tolerância de Fagerstron $>7$ em $73.2 \%$ dos casos de câncer, contra $43.5 \%$ dos controles $(\mathrm{p}=0.001)$. A proporção de pacientes deprimidos foi mais elevada no grupo do cancer 
$(37.5 \%$ x $17.6 \%)$. A regressão logística, ajustada para a idade e o consumo do tabaco, apontou que uma contagem de questionário de tolerância de Fagerstron $>7$ tem uma razão de chance para câncer de 3.45 (CI 95\% 1.52 - 7.83, p $=0.003)$.

CONCLUSÃO: Resultado no questionário de tolerância de
Fagerstron maior que 7 foi identificado como um fator de risco para cancer em fumantes com consumo similar do tabaco.

UNITERMOS: Cessação de tabagismo. Teste de Fagerström. Cancer. Tabaco.

\section{REFERENCES}

1. Zheng T, Holford T, Chen Y, Jiang P, Zhang B, Boyle P. Risk of tongue cancer asssociated with tobacco smoking and alcohol consumption:a case-control study. Oral Oncol. 1997;33(2):82-5.

2. Spitz MR, Fueger JJ, Goepfert H, Hong WK, Newell GR. Squamous cell carcinoma of the upper aerodigestive tract. A case comparison analysis. Cancer. 1988;61(1):203-8.

3. Peto R, Darby S, Deo H, Silcocks P, Whitley E, Doll R. Smoking, smoking cessation, and lung cancer in the UK since 1950:combination of national statistics with two case-control studies. Bmj. 2000;321(7257):323-9.

4. Osann KE, Lowery JT, Schell MJ. Small cell lung cancer in women:risk associated with smoking, prior respiratory disease, and occupation. Lung Cancer. 2000;28(1):1-10.

5. Fuchs CS, Colditz GA, Stampfer MJ, Giovannucci EL, Hunter DJ, Rimm EB et al. A prospective study of cigarette smoking and the risk of pancreatic cancer. Arch Intern Med. 1996;156(19):2255-60.

6. Cinciripini PM, Hecht SS, Henningfield JE, Manley MW, Kramer BS. Tobacco addiction:implications for treatment and cancer prevention. J Natl Cancer Inst. 1997;89(24):1852-67.

7. Shields PG. Molecular epidemiology of smoking and lung cancer Oncogene. 2002;21(45):6870-6.

8. Da Costa CL, Younes RN, Lourenco MT. Stopping smoking:a prospective, randomized, double-blind study comparing nortriptyline to placebo. Chest. 2002;122(2):403-8.
9. Jimenez-Ruiz CA, Masa F, Miravitlles M, Gabriel R, Viejo JL, Villasante C, et al. Smoking characteristics:differences in attitudes and dependence between healthy smokers and smokers with COPD. Chest. 2001;119(5):1365-70.

10. Mikami I, Akechi T, Kugaya A, Okuyama T, Nakano T, Okamura $\mathrm{H}$, et al. Screening for nicotine dependence among smoking-related cancer patients. Jpn J Cancer Res. 1999;90(10):1071-5.

11. Seersholm N, Nielsen NH, Tonnesen P. Self-reported smoking habits, biochemical markers, and nicotine dependence in a sample of the Danish population. J R Soc Health. 1999;119(2):92-6.

12. vonAmmon Cavanaugh S, Wettstein RM. Emotional and cognitive dysfunction associated with medical disorders. J Psychosom Res. 1989;33(4):505-14

13. Massie MJ, Popkin MK. Depressive disorders in Psycho-Oncology. Holland JC. Oxford University Press. 1998:518-540.

14. Breslau N, Kilbey MM, Andreski P. Nicotine dependence and major depression. New evidence from a prospective investigation. Arch Gen Psychiatry. 1993;50(1):31-5.

15. Schnoll RA, Zhang B, Rue M, Krook JE, Spears WT, Marcus AC, et al. Brief physician-initiated quit-smoking strategies for clinical oncology settings:A trial coordinated by the Eastern Cooperative Oncology Group. J Clin Oncol. 2003;21:355-365. 
16. Pomerleau CS, Carton SM, Lutzke ML, Flessland KA, Pomerleau OF. Reliability of the Fagerstrom Tolerance Questionnaire and the Fagerstrom Test for Nicotine Dependence. Addict Behav. 1994;19(1):33-9.

17. Pomerleau CS, Pomerleau OF, Majchrzak MJ, Kloska DD, Malakuti R. Relationship between nicotine tolerance questionnaire scores and plasma cotinine. Addict Behav. 1990;15(1):73-80.

18. Etter JF, Vu Duc T, Perneger TV. Saliva cotinine levels in smokers and nonsmokers. Am J Epidemiol. 2000;151(3):251-8.

19. Stanton WR, McClelland M, Elwood C, Ferry D, Silva PA. Prevalence, reliability and bias of adolescents' reports of smoking and quitting. Addiction. 1996;91(11):1705-14
20. Westman EC, Behm FM, Rose JE. Smoking behavior on the first day of a quit attempt predicts long-term abstinence. Arch Intern Med. 1997;157(3):335-40.

21. Dale LC, Glover ED, Sachs DP, Schroeder DR, Offord KP, Croghan IT, et al. Bupropion for smoking cessation :predictors of successful outcome. Chest. 2001;119(5):1357-64.

22. Breslau N, Johnson EO. Predicting smoking cessation and major depression in nicotine-dependent smokers. Am J Public Health. 2000;90(7):1122-7 